\title{
Daily intakes of copper, zinc and arsenic in drinking water by population of Shanghai, China
}

\author{
Peng $\mathrm{Xu}^{\mathrm{a}}$, Shengbiao Huang ${ }^{\mathrm{a}}$, Zijian Wang ${ }^{\mathrm{a}, *}$, Gustavo Lagos ${ }^{\mathrm{b}}$ \\ ${ }^{a}$ State Key Laboratory of Environmental Aquatic Chemistry, Research Center for Eco-Environmental Sciences, \\ Chinese Academy of Sciences, Shuangqing Rd. 18, Haidian District, Beijing 100085, PR China \\ ${ }^{\mathrm{b}}$ Faculty of Engineering, Catholic University of Chile, Santiago, Chile
}

Received 27 January 2005; accepted 25 May 2005

Available online 1 September 2005

\begin{abstract}
Daily intakes of metals in drinking water are of extreme importance in risk assessment to human health. Some papers focused on this topic, but most of them did not consider the effect of age, gender and work location on daily intakes of metals in drinking water. The objective of present paper is to estimate the levels of $\mathrm{Cu}, \mathrm{Zn}$ and As ingestion in drinking water in Shanghai, China and the effect of age, gender and work location on daily intakes of these metals. It was also the first time that such a detailed investigation on daily intakes of metals in drinking water was carried out in China in recent years. Drink/Sample (D/S) method was used to estimate the daily intakes of $\mathrm{Cu}, \mathrm{Zn}$ and $\mathrm{As}$ in drinking water. The mean concentrations of $\mathrm{Cu}, \mathrm{Zn}$ and $\mathrm{As}$ in drinking water were $10.8 \mu \mathrm{g} / 1,0.29 \mathrm{mg} / 1$ and $0.91 \mu \mathrm{g} / 1$, which were lower than U.S. EPA's Drinking Water Equivalent Level (DWEL) and WHO guideline values. The average daily intakes of $\mathrm{Cu}, \mathrm{Zn}$ and As in drinking water was $21.12 \mu \mathrm{g} / \mathrm{d}, 0.65 \mathrm{mg} / \mathrm{d}$, and $1.83 \mu \mathrm{g} / \mathrm{d}$, which were on average $0.01 \%, 1.1 \%$ and $1.5 \%$ of the provisional maximum tolerable daily intake (PMTDI) set by the Joint FAO/ WHO Expert Committee. There was a significant difference in daily intake of $\mathrm{Zn}$ for different work locations $(P=0.04)$. But no other significant differences in daily intakes of metals in drinking water were found according to age, gender and work location. (C) 2005 Elsevier B.V. All rights reserved.
\end{abstract}

Keywords: Daily intake; Drinking water; Metals

\section{Introduction}

Human being's essential requisites of air, water and food contain trace amounts of a wide range of ele-

* Corresponding author. Tel.: +86 106284 9140; fax: +86 10 62923543.

E-mail address: wangzj@mail.rcees.ac.cn (Z. Wang). ments, some of which plays a significant role in biochemical processes (Pirrone and Keeler, 1996; Raghunath et al., 1997; Tripathi et al., 1999).

Because the levels of trace elements in food and water generally reflect trace metals burden in the environment, the amount of metals ingested through food and water is of extreme importance in risk assessment to human health (Barnard et al., 1997; Tripathi et al., 
1997). It is also important to estimate the daily intakes of trace elements for populations in different geological locations in the world, where civilization level, living habit, economic situation and other factors are significantly different from each other. However, information on these topics is scarce, especially when dealing with developing countries.

The estimation of daily intakes of trace metals in drinking water should consider the concentration and dose ingested (Adgate et al., 2001; Maclntosh et al., 2001; Tsai et al., 2003). The estimation also depends on people's water consumption habits. Presently, most studies on daily intakes in drinking water rely on the water consumption hypothesis of Environmental Protection Agency (EPA) and World Health Organization (WHO) that may not correspond to the actual behavior of study population regarding tap water drinking. To accurately assess daily intakes in drinking water, it is important to obtain data on people's actual water consumption habits.

The objective of the present paper was to assess daily intakes of $\mathrm{Cu}, \mathrm{Zn}$ and As in drinking water in a test population in Shanghai, China and the effects of gender, age and work location on daily intakes of those metals in drinking water. Another objective is to construct a database of water quality variables as well as water consumption habits for a representative sample of the population of Shanghai, China in the summer of 2003.

\section{Materials and methods}

\subsection{Drink/sample method}

Drink/Sample method (D/S method) created originally by studies on exposure to trace elements in food and beverages and later applied to drinking water consists of sampling each time an individual has a drink containing drinking water, and recording the volume he or she drank. If participants drank boiled tap water from the same thermos bottle, they should only take one sample. Due to time and money constraints, it was decided that only 163 volunteers would participate in this study. These volunteers were selected in a joint manner with Central Viewer Survey and Consulting Center-Taylor
Nelson Sofres (CVSC-TNS) Research Company. The volunteers were selected to represent blocks of residences, socio-economic levels in society and age groups in the population. Visits were carried out in July 2003 by qualified inquirers to evaluate an individual's past $24 \mathrm{~h}$ water consumption and explain how to fill in the questionnaire.

The water samples were stored in polyethylene bottles, pre-washed with concentrated nitric acid $(1: 1)$ and after collection, nitric acid $(0.1 \% \mathrm{v} / \mathrm{v})$ was added as a preservative (Chatterjee et al., 1993). The water was acidified with $50 \% \mathrm{v} / \mathrm{v}$ nitric acid.

\subsection{Measurement methodology}

The concentrations of $\mathrm{Cu}$ were determined by graphite furnace atomic absorption spectrometry (GFAAS, Perkin-Elmer 3100, Conn., USA). Concentrations of $\mathrm{Zn}$ were determined by flame atomic absorption spectrometry (Model Z-6100, Hitachi CO. Tokyo, Japan). Concentrations of As were determined by Atomic Fluorescence Spectrometer (AF-610A, BRAIC CO. Beijing, China). The concentrations of metals were determined according to the method described by QA/QC procedures employed by EPA for these types of operations and improved for the different stages mentioned (USEPA, 1991a,b, 1993, 1994, 1995, 1997).

Non-parametric methods were chosen for the data that did not follow a normal distribution using the Kolmogorov-Smirnov test. Mann-Whitney $U$-test was used in order to analyze differences between males and females for daily intakes. MannWhitney $U$-test was also used in order to analyze differences between different work locations. Kruskal-Wallis $H$-test was used in order to analyze differences among different age groups. A statistically significant difference was set at $P<0.05$. Statistical analyses were conducted by means of SPSS for Windows (version 10.0).

\section{Results and discussion}

\subsection{Volumes of drinking water}

The volunteers were divided according to their age, gender and work location (Table 1). Water consump- 
Table 1

Characteristics of volunteers and averages of drinking content and weight of volunteers in $24 \mathrm{~h}$

\begin{tabular}{|c|c|c|c|c|}
\hline & $\begin{array}{l}\text { Number of } \\
\text { volunteers }\end{array}$ & $\%$ & $\begin{array}{l}\text { Daily water } \\
\text { consumption (1/d) }\end{array}$ & $\begin{array}{l}\text { Weight } \\
(\mathrm{kg})\end{array}$ \\
\hline $\mathrm{AM}^{\prime}$ & 81 & 49.7 & 2.1 & 66.9 \\
\hline $\mathrm{AF}$ & 82 & 50.3 & 1.9 & 56.1 \\
\hline $\mathrm{OM}^{\prime}$ & 9 & 5.5 & 2.2 & 66.9 \\
\hline OF & 9 & 5.5 & 2.0 & 61.0 \\
\hline $\mathrm{MM}^{\prime}$ & 55 & 33.7 & 2.1 & 67.8 \\
\hline $\mathrm{MF}$ & 55 & 33.7 & 2.0 & 57.4 \\
\hline $\mathrm{MM}^{\prime}-1$ & 45 & 27.6 & 2.1 & 70.7 \\
\hline MF-1 & 37 & 22.7 & 1.9 & 55.7 \\
\hline $\mathrm{MM}^{\prime}-2$ & 10 & 6.1 & 2.1 & 63.4 \\
\hline MF-2 & 18 & 11.0 & 2.0 & 57.9 \\
\hline $\mathrm{YM}^{\prime}$ & 17 & 10.4 & 1.7 & 63.8 \\
\hline YF & 18 & 11.0 & 1.7 & 50.0 \\
\hline
\end{tabular}

$\mathrm{AM}^{\prime}$ : man; $\mathrm{AF}$ : woman; $\mathrm{OM}^{\prime}$ : old man; $\mathrm{OF}$ : old woman; $\mathrm{MM}^{\prime}$ : middle man; MF: middle woman; $\mathrm{MM}^{\prime}-1$ : middle man who work inside the house; MF-1: middle woman who work inside the house; $\mathrm{MM}^{\prime}$-2: middle man who work outside the house; MF-2: middle woman who work outside the house; $\mathrm{YM}^{\prime}$ : young man; YF: young woman.

tion volumes according to age, gender and work location were also evaluated (Table 1). The mean consumption volume of drinking water was estimated to be $2.0 \mathrm{l} / \mathrm{d}$, which was consistent with U.S. EPA's hypothesis $(2 \mathrm{l} / \mathrm{d})$. And it was higher than the general consumption of Canadians (1.6 1/d) and Americans $(1.4$ 1/d) (Levallois et al., 1998). The volumes of water consumed by volunteers in different age, gender and work location groups were between 1.7 and $2.2 \mathrm{l} / \mathrm{d}$.

\subsection{Chemical results}

Concentrations of $\mathrm{Cu}, \mathrm{Zn}$ and As were listed in Table 2. Concentrations of $\mathrm{Cu}, \mathrm{Zn}$ and As did not follow a normal distribution using the KolmogorovSmirnov test $(P<0.05)$. According to WHO, natural $\mathrm{Cu}$ concentrations in drinking-water are around a few micrograms per liter (WHO, 1981). Cu concentration in water distributed by copper pipes depends on such properties as hardness, $\mathrm{pH}$, anion concentration, oxygen concentration, and temperature. (EPA, 1987; Slooff et al., 1989; Alam and Sadiq, 1989). The highest $\mathrm{Cu}$ concentration in tap water was reported to be $1.2 \mathrm{mg} / \mathrm{l}$ in Chile, $4.8 \mathrm{mg} / \mathrm{l}$ in USA, $0.1 \mathrm{mg} / \mathrm{l}$ in Saudi Arabia, and $1.9 \mu \mathrm{g} / \mathrm{l}$ in India. (Lagos et al., 1999; Al-SalehU and Al-Doush, 1998; Tarit et al., 2003). In our study, the highest $\mathrm{Cu}$ concentration was $32.1 \mu \mathrm{g} / \mathrm{l}$, which was much lower than U.S. EPA's Drinking Water Maximum Contaminant Level Goal (1.3 mg/l) (EPA, 2002; Kenneth and Gilbert, 2002) and WHO guideline value (2 mg/l) (WHO, 1993).

$\mathrm{Zn}$ concentration is usually low in drinking water, compared to the WHO guideline value $(3 \mathrm{mg} / \mathrm{l})$ (WHO, 1993). The $\mathrm{Zn}$ concentration in tap water can be much higher as a result of the leaching of $\mathrm{Zn}$ from piping and fittings (WHO, 1996). The mean $\mathrm{Zn}$ concentration in our study was $0.29 \mathrm{mg} / \mathrm{l}$, which was lower than U.S. EPA's Drinking Water Equivalent Level $(10 \mathrm{mg} / \mathrm{l})$ and WHO guideline value for organoleptic properties (3 mg/l) (EPA, 2002; WHO, 1993). The highest $\mathrm{Zn}$ concentration was $1.63 \mathrm{mg} / \mathrm{l}$, which was very close to the WHO guideline value $(3 \mathrm{mg} / \mathrm{l})$. The measured values for $\mathrm{Zn}$ in drinking water were compared to the results of other studies. Even higher $\mathrm{Zn}$ concentrations (up to $24 \mathrm{mg} / \mathrm{l}$ ) were reported in a Finnish survey (WHO, 1996). A recent study showed that the mean $\mathrm{Zn}$ concentration in drinking water in West Bengal, India was $51.8 \mu \mathrm{g} / \mathrm{l}$ (Tarit et al., 2003).

According to WHO, inorganic As compounds are classified by IARC in Group 1 (carcinogenic to humans) on the basis of sufficient evidence for carcinogenicity in humans and limited evidence for carcinogenicity in animals (IARC, 1987; Luten et al., 1982). The level of As in natural waters generally varies between 1 and $2 \mu \mathrm{g} / \mathrm{l}$ (Hindmarsh and Mcurdy, 1986). In some parts of the world - Taiwan, western South America, Bangladesh, Inner Mongolia - As is present in high concentrations naturally in drinking water, at levels ranging from several hundred to well over $1000 \mu \mathrm{g} / \mathrm{l}$. In some parts of the United States, the population is also exposed to levels of As in drinking water higher than $50 \mu \mathrm{g} / \mathrm{l}$ (Kenneth and Gilbert, 2002). The mean As concentration in the water samples in Shanghai was much lower than that in those countries and ranged from 0.00 to $5.98 \mu \mathrm{g} / \mathrm{l}$, with a mean concentration of $0.91 \mu \mathrm{g} / 1$ and a standard devi-

Table 2

Water quality variables measured in drinking water samples from Shanghai, China, 2003

\begin{tabular}{lcllll}
\hline Parameters & Mean & S.D. & Maximum & Minimum & $n$ \\
\hline Total $\mathrm{Cu}(\mu \mathrm{g} / \mathrm{l})$ & 10.8 & 0.4 & 32.1 & 1.3 & 195 \\
Total $\mathrm{Zn}(\mathrm{mg} / \mathrm{l})$ & 0.29 & 0.04 & 3.00 & $\mathrm{ND}$ & 188 \\
Total $\mathrm{As}(\mu \mathrm{g} / \mathrm{l})$ & 0.91 & 0.05 & 6.00 & $\mathrm{ND}$ & 189 \\
\hline
\end{tabular}


ation of 0.05 . The current WHO recommended Guideline Value for As in drinking water is $10 \mu \mathrm{g} / 1$, whereas many developing countries (including China) still have a previous value used by WHO, of $50 \mu \mathrm{g} / \mathrm{l}$. The standard value for arsenic in drinking water in Australia has been set at $7 \mu \mathrm{g} / \mathrm{l}$ (NHMRC, 1996). It was important to note that the maximum As concentration in our study was very close to Australia's standard.

\subsection{Daily intakes of $\mathrm{Cu}, \mathrm{Zn}$ and As in drinking water}

Table 3 showed the results of daily intakes of $\mathrm{Cu}$, $\mathrm{Zn}$ and $\mathrm{As}$ in drinking water. $\mathrm{Cu}$ is ingested by humans mainly through food and drinking water. Drinking-water can contribute a significant proportion of the daily $\mathrm{Cu}$ intake if it has flowed through copper installations (EPA, 1987; Slooff et al., 1989). A provisional maximum tolerable daily intake (PMTDI) of $0.5 \mathrm{mg} / \mathrm{d} / \mathrm{kg}$ of body weight was established by Joint FAO/WHO Expert Committee on Food Additives (JECFA) (WHO, 1982a,b). According to WHO, an allocation of $10 \%$ of the PMTDI to drinking-water gives a guideline value of $50 \mu \mathrm{g} / \mathrm{d} / \mathrm{kg}$. In our study, the average daily intake of $\mathrm{Cu}$ in drinking water was $21.12 \mu \mathrm{g} / \mathrm{d}$ which was only $0.01 \%$ of PMTDI for

Table 3

Daily intakes of $\mathrm{Cu}, \mathrm{Zn}$ and As in drinking water by general population of Shanghai

\begin{tabular}{llll}
\hline & As $(\mu \mathrm{g} /$ day $)$ & $\mathrm{Cu}(\mu \mathrm{g} /$ day $)$ & $\mathrm{Zn}(\mathrm{mg} /$ day $)$ \\
\hline All & $0.65 \pm 1.27$ & $21.12 \pm 12.63$ & $1.83 \pm 1.36$ \\
AM $^{\prime}$ & $1.88 \pm 1.34$ & $21.32 \pm 12.55$ & $0.69 \pm 1.42$ \\
AF & $1.77 \pm 1.39$ & $21.01 \pm 12.79$ & $0.62 \pm 1.12$ \\
OM$^{\prime}$ & $2.27 \pm 1.34$ & $24.47 \pm 10.32$ & $0.72 \pm 0.83$ \\
OF $^{\prime}$ & $2.85 \pm 2.43$ & $24.44 \pm 15.44$ & $0.53 \pm 0.27$ \\
MM $^{\prime}$ & $1.95 \pm 1.46$ & $21.98 \pm 13.80$ & $0.77 \pm 1.66$ \\
MF & $1.70 \pm 1.28$ & $20.11 \pm 18.43$ & $0.70 \pm 0.99$ \\
MM'-1 & $2.07 \pm 1.58$ & $22.69 \pm 15.92$ & $0.82 \pm 2.38$ \\
MF-1 & $1.92 \pm 1.43$ & $20.85 \pm 11.44$ & $0.65 \pm 0.95$ \\
MM'-2 $^{\prime}$ & $1.41 \pm 1.23$ & $18.79 \pm 13.14$ & $0.71 \pm 0.58$ \\
MF-2 & $0.94 \pm 0.86$ & $18.58 \pm 6.44$ & $0.81 \pm 1.63$ \\
YM $^{\prime}$ & $1.45 \pm 0.67$ & $23.47 \pm 18.43$ & $0.42 \pm 0.55$ \\
YF $^{\prime}$ & $1.46 \pm 0.80$ & $16.04 \pm 7.39$ & $0.42 \pm 0.99$ \\
\hline AM $^{\prime}$ & AF $:$ m &
\end{tabular}

$\mathrm{AM}^{\prime}$ : man; $\mathrm{AF}$ : woman; $\mathrm{OM}^{\prime}$ : old man; $\mathrm{OF}$ : old woman; $\mathrm{MM}^{\prime}$ : middle man; MF: middle woman; $\mathrm{MM}^{\prime}-1$ : middle man who work inside the house; MF-1: middle woman who work inside the house; $\mathrm{MM}^{\prime}$-2: middle man who work outside the house; MF-2: middle woman who work outside the house; $\mathrm{YM}^{\prime}$ : young man; YF: young woman. drinking water and food. The recommended daily intake of copper in the United Kingdom is $1.2 \mathrm{mg}$ for adults. The recommended dietary intake in the United States is 1.5-3.0 mg for adults (FAB, 1989; WHO, 1996). The average daily intake of $\mathrm{Cu}$ contained in drinking water by Shanghai sample population was $1.8 \%$ of the United Kingdom recommendations for minimum total ingestion of $\mathrm{Cu}$ for adults. In west Bangladesh, India the daily intake of $\mathrm{Cu}$ in drinking water was about $0.92 \mu \mathrm{g} / \mathrm{d}$, which was much less than that in our study (Tarit et al., 2003).

Under certain circumstances, tap water can provide up to $10 \%$ of the daily intake of $\mathrm{Zn}$ (Gillies and Paulin, 1982). JECFA proposed a daily dietary requirement of $\mathrm{Zn}$ of $0.3 \mathrm{mg} / \mathrm{kg}$ of body weight and a provisional maximum tolerable daily intake (PMTDI) of $1.0 \mathrm{mg} / \mathrm{kg}$ of body weight (WHO, 1982a,b). WHO recommended that the daily requirement of $\mathrm{Zn}$ for adult humans is $15-22 \mathrm{mg} / \mathrm{d}$ (WHO, 1996). In our study, the daily intake of $\mathrm{Zn}$ was $0.66 \mathrm{mg} / \mathrm{d}$, which was $1.1 \%$ of the PMTDI. It was only $4.4 \%$ of the WHO recommendations for minimum total ingestion of $\mathrm{Zn}$ for adults. It was important to note that the maximum daily intake of $\mathrm{Zn}$ through drinking water was $10.23 \mathrm{mg} / \mathrm{d}$ in our study, which was $68.2 \%$ of the WHO recommendations for minimum total ingestion of $\mathrm{Zn}$ for adults. A recent study showed that the daily intake of $\mathrm{Zn}$ in drinking water was about $0.16 \mathrm{mg} / \mathrm{d}$ in west Bangladesh, India (Tarit et al., 2003).

A critical source of As intake for the general population is the drinking water. A value of $13 \mu \mathrm{g}$ / 1 may be derived (assuming a 20\% allocation to drinking-water) on the basis of the provisional maximum tolerable daily intake (PMTDI) of inorganic As of $2 \mu \mathrm{g} / \mathrm{kg}$ of body weight set by the Joint FAO/WHO Expert Committee on Food Additives (JECFA) in 1983 (WHO, 1989). In our study, the average daily intake of As was $1.83 \mu \mathrm{g} / \mathrm{day}$, which was $1.5 \%$ of the PMTDI. Results from west Bangladesh survey showed that in arsenic affected area, water contributes about $75 \%$ of daily intake of As (Tarit et al., 2003).

Our results suggested that ingestion of these metals in drinking water were associated with a non-significant potential threat to human health for the general population of Shanghai, China.

Table 3 also showed the results of daily intakes of $\mathrm{Cu}, \mathrm{Zn}$ and $\mathrm{As}$ in drinking water in segments of the 
population. It was important to note that gender, age and work location affected the daily intakes of $\mathrm{Cu}, \mathrm{Zn}$ and As in drinking water. Our results showed that older people had significant higher daily intakes than the younger ones. But no significant differences in daily intakes of $\mathrm{Cu}, \mathrm{Zn}$ and As among different age groups were found $(P>0.05)$. For example, the daily intake of As was $2.66 \mu \mathrm{g} / \mathrm{d}$ for over 64 years, versus $1.85 \mu \mathrm{g} / \mathrm{d}$ for $20-64$ years old and $1.46 \mu \mathrm{g} / \mathrm{d}$ for less than 20 years. This was largely due to the fact that older people drink more water than younger ones. Data on daily intakes according to the gender of the consumer was also assessed. In the present study we also could not find gender related differences $(P>0.05)$. But there was a tendency for males to have higher mean daily intakes of $\mathrm{Cu}, \mathrm{Zn}$ and $\mathrm{As}$ than females $(21.32 \mu \mathrm{g} / \mathrm{d}$ for $\mathrm{Cu}, 0.69 \mathrm{mg} / \mathrm{d}$ for $\mathrm{Zn}$ and $1.88 \mu \mathrm{g} / \mathrm{d}$ for As vs. $21.01 \mu \mathrm{g} / \mathrm{d}$ for $\mathrm{Cu}, 0.62 \mathrm{mg} / \mathrm{d}$ for $\mathrm{Zn}$ and $1.77 \mu \mathrm{g} / \mathrm{d}$ for As). Our results indicated that the difference of water consumption between males and females could be considered as an important factor. In general, males consumed more water than females $(2.1 \mathrm{l} / \mathrm{d}$ vs. $1.9 \mathrm{l} / \mathrm{d})$. Work location also affected the daily intakes of metals in drinking water. For example, middle aged people who worked inside the house had lower daily intakes of $\mathrm{Zn}$ than those who worked outside the house $(0.74 \mathrm{mg} / \mathrm{d}$ vs. 0.76 $\mathrm{mg} / \mathrm{d}$ ). There was a significant difference in daily intake of $\mathrm{Zn}$ for different work locations $(P=0.04)$. But No such difference was found for daily intakes of $\mathrm{Cu}$ and $\mathrm{As}(P>0.05)$. The non-significant results in our study may be due to our small samples.

\section{Conclusion}

Daily intakes of $\mathrm{Cu}, \mathrm{Zn}$ and As in drinking water by Shanghai people were on average $0.01 \%, 1.1 \%$ and $1.5 \%$ of the provisional maximum tolerable daily intake (PMTDI) set by the Joint FAO/WHO Expert Committee. That is to say that ingested metals in drinking water contributed to a minor fraction of the total metals intake, and current drinking water levels of metals were associated with a non-significant potential threat to human health for general population of Shanghai, China. Our results also showed that gender, age and work locations all affected drinking water consumption as well as daily intakes of metals in drinking water, but there were no statistically significant differences.

\section{Acknowledgements}

This project was financially supported by the International Copper Association (H-AS-02-02) and by the Chinese Academy of Sciences (KZCX3-SW-431).

\section{References}

Adgate HL, Barr DB, Clayton CA. Measurement of children's intakes to pesticides: analysis of urinary metabolite levels in a probability-based sample. Environ Health Perspect 2001;109: $583-9$.

Alam I, Sadiq M. Metal contamination of drinking water from the corrosion of distribution pipes. Environ Pollut 1989;57:167-78.

Al-SalehU I, Al-Doush I. Survey of trace elements in household and bottled drinking water samples collected in Riyadh, Saudi Arabia. Sci Total Environ 1998;216:181-92.

Barnard C, Daberkow S, Padgitt M, Smith ME, Uri ND. Alternative measures of pesticide use. Sci Total Environ 1997;203:229-44

Chatterjee A, Das D, Chakraborti D. A study of groundwater contamination by arsenic in the residential area of Behala, Calcutta, due to industrial pollution. Environ Pollut 1993;80: $57-65$.

Food Administration Board. Recommended dietary allowance. 10th ed. National Research Council. Washington, DC: National Academy Press; 1989.

Gillies ME, Paulin HV. Estimations of daily mineral intakes from drinking water. Hum Nutr Appl Nutr 1982;36:287-92.

Hindmarsh JT, McCurdy RF. Clinical and environmental aspects of arsenic toxicity. CRC Crit Rev Clin Lab Sci 1986;23: $315-47$

International Agency for Research on Cancer. Overall evaluations of carcinogenicity: an updating of IARC monographs volumes 142. IARC monographs on the evaluation of carcinogenic risk to humans. Lyon; 1987. p. 100-6. Suppl. 7.

Joint FAO/WHO Expert Committee on Food Additives. Evaluation of certain food additives and contaminants: twenty-sixth report of the World Health Organization. WHO technical report series. Geneva; 1982a. p. 31-2.

Joint FAO/WHO Expert Committee on Food Additives. Toxicological evaluation of certain food additives. WHO food additives series. Cambridge: Cambridge University Press; 1982b. p. $265-96$.

Joint FAO/WHO Expert Committee on Food Additives. Toxicological evaluation of certain food additives and contaminants. WHO food additives series. Cambridge: Cambridge University Press; 1989. p. 155-62.

Kenneth GB, Gilbert LR. Arsenic, drinking water, and health: a position paper of the American Council on Science and Health. Regul Toxicol Pharm 2002;36:162-76. 
Lagos GE, Maggi LC, Reveco F. Model for estimating of human exposure to copper in drinking water. Sci Total Environ 1999;239:49-70.

Levallois P, Guevin N, Gingras S, Levesque B. New patterns of drinking-water consumption: results of a pilot study. Sci Total Environ 1998;209:233-41.

Luten JB, Riekwel-Booy G, Rauchbaar A. Occurrence of arsenic in plaice (Pleuronectes platessa), nature of organo-arsenic compound present and its excretion by man. Environ Health Perspect 1982;45:165-70.

Macintosh DL, Kabiru GW, Ryan PB. Longitudinal investigation of dietary intakes to selected pesticides. Environ Health Perspect 2001;109:145-50.

National Health and Medical Research Council (NHMRC). Australian drinking water guidelines Agriculture and Resource Management Council of Australia and New Zealand; 1996.

Pirrone N, Keeler GJ. A preliminary assessment of the urban population in the Great Lakes region. Sci Total Environ 1996;189:91-8.

Raghunath R, Tripathi RM, Khandekar RN, Nambi KSV. Retention times of $\mathrm{Pb}, \mathrm{Cd}, \mathrm{Cu}$ and $\mathrm{Zn}$ in children's blood. Sci Total Environ 1997;207:133-9.

Slooff W, et al, editors. Integrated criteria document copper. Bilthoven, Netherlands: National Institute of Public Health and Environmental Protection; 1989. Report no. 758474009.

Tarit R, Hiroshi T, Masanori A. Survey of arsenic and other heavy metals in food composites and drinking water and estimation of dietary intake by the villagers from an arsenic-affected area of West Bengal, India. Sci Total Environ 2003;308:15-35.

Tripathi RM, Raghunath R, Krishnamoorthy TM. Dietary intakes of heavy metals in Bombay City, India. Sci Total Environ 1997;208:149-59.

Tripathi RM, Radha R, Sastry VN, Krishnamoorthy TM. Daily intakes of heavy metals by infants through milk and milk products. Sci Total Environ 1999;227:229-35.
Tsai SY, Chou HY, The HW. The effects of chronic arsenic intakes from drinking water on the neurobehavioral development in adolescence. Neurol Toxicol 2003;24:747-53.

USEPA. Summary review of the health effects associated with copper: health issue assessment, EPA-600/8-87-001. USEPA; 1987.

USEPA. Maximum contaminant level goals and national primary drinking water regulations for lead and copper; final rule, 40 CRF. Parts 141 and 142. Fed. Reg. 56, 110. USEPA; 1991a.

USEPA. Preparation aids for the development of category I quality assurance project plan. EPA/600/8-91/003. Washington D.C., USA; $1991 b$.

USEPA. Methods for the determination of inorganic substances in environmental. U.S. Environmental Protection Agency, Office of Research and Development, Environmental Monitoring Systems Laboratory, Cincinnati, OH. EPA/600/R-93/100; 1993.

USEPA. Laboratory data validation functional guidelines for evaluating inorganic analyses. Publication 9240.1-26, EPA/540/R/ 94/083, December, Washington D.C., USA; 1994.

USEPA. Guidelines establishing test procedures for the analysis of pollution: new methods. Proposed Rule, 40 CFR Part 136, vol. 60, Number 201; 1995.

USEPA. Manual for the certification of laboratory analyzing drinking water, criteria and procedures quality assurance. 4th ed. EPA 815-B-97-001, Washington D.C., USA; 1997.

USEPA. 2002 edition of the drinking water standards and health advisories. EPA 822/R/02/038. Washington D.C., USA; 2002.

World Health Organization. Environmental health criteria. Arsenic. Geneva: WHO; 1981.

World Health Organization. Guidelines for drinking water quality. 2nd ed. Recommendations. Geneva: WHO; 1993. p. 1-190.

World Health Organization. Guidelines for drinking-water quality - health criteria and other supporting information. Geneva: WHO; 1996. 